British Medical fournal, 1968a, 1, 690.

British Medical Fournal, 1968b, 2, 187 .

Cabal, D. A. (1965). British Medical fournal, 2, 1180.

Doll, R., and Hill, A. B. (1964). British Medical fournal, 1, 1399.

Drill, V. A., and Calhoun, D. W. (1968). Fournal of the American Medical Associetion, 206, 77.

Frederiksen, H., and Ravenholt, R. T. (1968). British Medical fournal, 4, 770.

Inman, W. H. W., and Vessey, M. P. (1968). British Medical fournal, 2, 193 .

Jeffconte, T. N. A., Miller, J., Roos, R. F., and Tindall, V. R. (1968). British Medical fournal, 4, 19.

Jick, H., et al. (1969). Lancet, 1, 539.
Kemsley, W. F. F., Billewicz, W. Z., and Thomson, A. M. (1962). British fournal of Preventive and Social Medicine, 16, 189.

Markush, R. E., and Seigel, D. G. (1969). American Fournal of Public Health, 59, 418.

Medical Research Council (1967). British Medical fournal, 2, 355.

Millar, D. G., and Robertson, E. G. (1968). British Medical fournal, 4, 452 .

Pike, M. C. (1969). To be published.

Registrar General (1966). Census 1961, England and Wales, Fertility Tables. London, H.M.S.O.

Salmon, M. L., Winkelman, J. Z., and Gay, A. J. (1968). Fournal of the American Medical Association, 206, 85.

Vessey, M. P., and Doll, R. (1968). British Medical fournal, 2, 199.

Vessey, M. P., and Weatherall, J. A. C. (1968). Lancet, 2, 94.

\title{
Thermal, Metabolic, Blood, and Circulatory Adjustments in Prolonged Outdoor Exercise
}

\author{
L. G. C. E. PUGH,* M.A., B.M., B.CH.
}

British Medical fournal, 1969, 2, 657-662

Summary : Thermal, metabolic, and circulatory responses were studied in six hill-walkers taking part in a 28 -mile $(45-\mathrm{km}$.) walk in rough country in autumn and winter, air temperatures being 6 to $12^{\circ} \mathrm{C}$. and -2 to $2^{\circ} \mathrm{C}$, respectively.

Though they were an apparently well-matched party, the walkers had to split into three pairs to avoid exhaustion. They adjusted their clothing so that mean skin temperatures were similar in both warm and cold conditions, the average value being $30.5^{\circ} \mathrm{C}$. compared with the resting comfort range of 33 to $34.5^{\circ} \mathrm{C}$. When, on the winter trial, skin temperatures were lowered by reduction of clothing, mean skin temperatures fell to 26.5 to $27.8^{\circ} \mathrm{C}$., one subject showing a value of $21 \cdot 3^{\circ} \mathrm{C}$. These temperatures were associated with moderate discomfort from cold.

Gut temperatures during exercise, measured with a radio piil, averaged 38.7 to $37.9^{\circ} \mathrm{C}$. on the autumn exercise. Slightly lower values were observed in winter, but this was associated with slower walking rather than cold stress. A fat and a thin subject walking together with minimal clothing showed widely different temperature responses, the fatter subject having a lower skin temperature and higher gut temperature than his companion. These results were compared with other results on extreme cold stress and discussed in relation to hypothermia. Heart rate and blood pressure findings were unremarkable, except for increased post-exercise heart rates and standing/lying heart rate differences, and a tendency to postural hypotension associated with exhaustion. Blood volume was not reduced in exhaustion and there were no significant changes in blood electrolytes or other constituents apart from a small rise in potassium. Ketonuria developed in all subjects.

\section{Introduction}

The investigations described in this article were part of an ertended inquiry into the causes of accidental hypothermia in hill-walkers and climbers in Britain. The intention was to follow body temperature changes during long-continued outdoor exercise in warm and cold conditions, and to look for circulatory and biochemical changes that might account for the severity of hypothermia in these cases.

\section{Methods}

The investigation took place in the Derbyshire Peak District and involved a 28 -mile $(45-\mathrm{km}$.) trek over the moors. Two trials were carried out, one in fine autumn weather (Edale I), the other in dry cold winter conditions (Edale II). Meteorological details are given in Table I. Six experienced hillwalkers acted as subjects (Table II). They supplied their own clothing, which consisted of a string vest, shirt, woollen sweater, anorak, long trousers, cotton drawers, thick woollen socks, and heavy boots. On the second exercise they were given special jeans, in which small slits had been cut for insertion of probe thermocouples. These slits were situated over each of Hardy's (1949) surface regions for the lower limb.

TABLE I.-Details of the Route and Weather Conditions Durixg 28-mile $(45-\mathrm{km}$.) Trek. Total Ascent, 3,780 ft. $(1,166 \mathrm{~m}$.). Total Descent, $3,840 \mathrm{ft}$. $(1,184 \mathrm{~m}$. $)$

\begin{tabular}{|c|c|c|}
\hline & $\begin{array}{l}\text { Edale I. } \\
\text { October }\end{array}$ & $\begin{array}{l}\text { Edale II. } \\
\text { January }\end{array}$ \\
\hline $\begin{array}{l}\begin{array}{l}\text { Air temperature }\left({ }^{\circ} \mathrm{C}\right) \\
\text { Wind velocity }\end{array}\left\{\begin{array}{l}\text { m.p.h. } \\
\text { k.p.h. }\end{array}\right. \\
\cdots\end{array}$ & $\begin{array}{l}+6 \text { to }+12 \\
\text { Calm to } 7 \\
\text { Calm to } 11 \\
\text { Nil }\end{array}$ & $\begin{array}{l}-2 \text { to }+2 \cdot 5 \\
10 \text { to } 18 \\
16 \text { to } 29 \\
\text { Nil }\end{array}$ \\
\hline $\begin{array}{l}\text { Cloud } \\
\text { Condition of terrain }\end{array}$ & Dry & $0-5 \mathrm{~cm}$. Snow \\
\hline 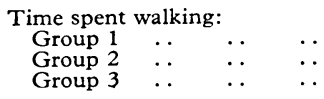 & $\begin{array}{l}\text { hr. } \min . \\
8 \\
83 \\
855 \\
858\end{array}$ & $\begin{array}{l}\text { hr. } \min . \\
814 \\
852 \\
910 \\
910\end{array}$ \\
\hline 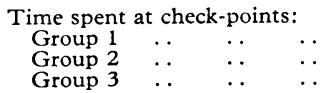 & $\begin{array}{ll}1 & 31 \\
1 & 53 \\
1 & 55\end{array}$ & $\begin{array}{ll}2 & 31 \\
2 & 53 \\
2 & 55\end{array}$ \\
\hline
\end{tabular}

TABLE II.-Physical Characteristics of Subjects. Skinfold Results are Means of Readings Taken Over 11 Regions of the Body Surface

\begin{tabular}{|c|c|c|c|c|c|c|c|c|}
\hline roup & Subject & $\begin{array}{c}\text { Age } \\
\text { in } \\
\text { Years }\end{array}$ & $\begin{array}{c}\text { Weight } \\
\text { (kg.) }\end{array}$ & $\begin{array}{l}\text { Height } \\
(\mathrm{cm} .)\end{array}$ & & $\begin{array}{c}\text { Mean } \\
\text { Skinfold } \\
(\mathrm{mm} .)\end{array}$ & $\begin{array}{c}\text { Blood } \\
\text { Volume } \\
\text { (ml./kg.) }\end{array}$ & $\begin{array}{c}\text { Total } \\
\text { Hb } \\
\text { (g. } / \mathbf{k g} .)\end{array}$ \\
\hline $\begin{array}{l}1 \\
2\end{array}$ & & $\begin{array}{l}25 \\
15 \\
24 \\
21\end{array}$ & $\begin{array}{l}75.7 \\
60.6 \\
61.2 \\
61 \cdot 6\end{array}$ & & & 4.4 & & $\begin{array}{l}11.7 \\
11.3 \\
11.6 \\
12.0 \\
12.3 \\
11.1\end{array}$ \\
\hline
\end{tabular}

There are six check-points along the route at which food and fluid were available. The subjects spent 10 to 20 minutes at each check-point in order to allow time for physiological observations. These consisted of heart rate, blood pressure, regional skin temperatures, and gut temperature. Urine samples were also collected.

On the first exercise (Edale I) the party set off in a single group at 08.45 hours, about one and a half hours after a normal breakfast. They were asked to walk as fast as they search, London N.W.3. 
could, and after two hours it was evident that the slower members would not be able to keep up. The party therefore split up into two groups of three, and later three groups of two men each. This grouping was adhered to throughout the second exercise. Table I contains details of the time taken to cover the route on each exercise and the time spent at check-points. On finishing, each subject continued walking near the laboratory until the observers were ready to begin their observations. This involved an extra half-hour of walking for some subjects.

The following observations were made on the evening before each exercise and again approximately 24 hours later on completing each exercise: body weight, skinfolds, E.C.G., heart rate, blood pressure, blood volume, haematocrit, and blood $\mathrm{pH}$. Venous blood samples were stored for subsequent determination of lactate, sugar, protein, and electrolytes. Blood volumes were measured in a sitting posture. The postexercise measurements were begun directly exercise ceased.

Skinfolds were measured with Harpenden callipers (Edwards et al. (1955) over 11 sites. Skin temperatures were measured with Ellab $^{1}$ probe thermocouples over five sites on Edale I and 14 sites on Edale II (Hardy, 1949). Gut temperatures $\left(T_{G}\right)$ were measured with the Wolff radio pill (Fox et al., 1962). The pills were administered before breakfast. Blood volumes were estimated with carbon monoxide by the method described by Pugh (1964a, 1969). Venous blood samples were drawn before and after administration of a known quantity of carbon monoxide, and analysed for carboxyhaemoglobin. Haematocrits were measured on 1-ml. aliquots from the control blood samples. Plasma volume and packed cell volume were calculated from the results thus obtained without correction for difference between venous and whole body haematocrit readings. Other subsamples were centrifuged to provide plasma for subsequent determination of plasma proteins and electrolytes, or diluted and deproteinized for subsequent determination of blood sugar and lactic acid. The plasma protein, electrolyte, and blood sugar determinations were carried out at the Radcliffe Infirmary, Oxford, by standard procedures. Metabolism was measured continuously on a seventh subject (J. C.) by means of the Wolff integrating-motor pneumotachograph (Wolff, 1958). Analysis of urine for the presence of ketone bodies was carried out by two semi-quantitative methods-Acetest and Ketostix. Each sample was tested by both methods in the field; these methods were found highly reliable in subsequent laboratory tests.

Calculation.-Weighted mean skin temperature $\left(\mathrm{T}_{\mathrm{s}}\right)$ was calculated by use of the following factors: forehead 0.0752 ; arm 0.0752 ; forearm 0.0752 ; hand 0.0538 ; trunk 0.3764 ; thigh 0.2044 ; leg 0.1398 , based on Hardy (1949), with allowance for foot temperature, which was not measured. Mean body temperature $\left(T_{B}\right)$ was calculated from the relation $T_{B}=0.66 T_{S}+0.33 T_{G}$ (Burton, 1935). Heat debt was calculated from the relation $S=\Delta T_{B} \times \mathbb{W} /$ S.A. $\times 0.83$, where $S$ is the heat debt in kcal./sq. m., $\Delta T_{B}$ is change in mean body temperature in degrees centigrade, $\mathrm{W}$ is body weight in kilograms, S.A. is surface area in square metres, and 0.83 is the specific heat of the body tissues (for references see Burton and Edholm, 1955).

\section{Results}

On the autumn exercise (Edale I) the weather was warm for walking (Table I) and the subjects were allowed to adjust their clothing to keep cool. During most of the day they walked in shirt-sleeves and there was considerable sweating on uphill sections. The subjects finished in a state of advanced fatigue, but only one (S. H. in group 2) was near the point of collapse, being confused, disorientated, and ataxic.

On the winter exercise (Edale II), which took place on a fine cold day with a strong wind, the subjects were asked to wear as little clothing as possible. They dispensed therefore with either their anoraks or sweaters during much of the day, but all of them wore gloves and four out of the six wore some form

${ }^{1}$ Elektrolaboratoriet Ellab A/S, Copenhagen BRH, Denmark. of head covering. Group 1, who were the fastest pair, walked in shirt-sleeves from check-point 2 to 4 (Fig. 1) and did not wear hats ; they also exposed their forearms and legs by rolling up their sleeves and trousers. At the first three check-points on Edale II all subjects said "they felt fine," but by checkpoint 4 all complained of being cold and most of them put on more clothing. The last two sections of the route were also more sheltered. Shivering was observed in only two subjectsnamely, S. H. at check-point 4 and R. R. at the finish. Subject B. N. was aggressive and uncooperative at check-points 3 and 4, and the team leader thought he was suffering from exposure ; later, however, he recovered. At the end of Edale II the subjects seemed rather less tired than they had been after Edale I.

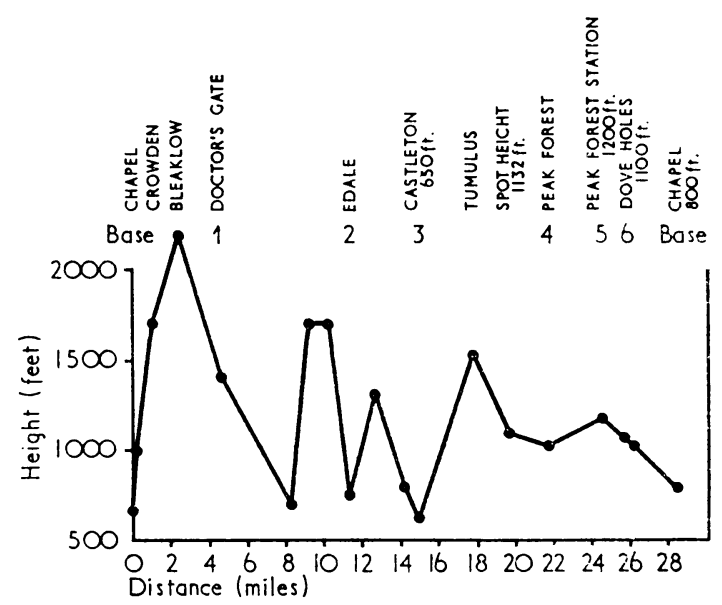

FIG. 1.-Details of route based on Ordnance Survey Sheets 101 and 102 .

\section{Skin Temperature}

Weighted mean skin temperatures at each check-point on Edale II are shown in Fig. 2. The numbers near each plotted point are the corresponding gut temperatures, while those in parenthesis are estimates of mean skin temperature on Edale I based on readings taken at five sites only; their reliability is perhaps not better than $\pm 1.0^{\circ} \mathrm{C}$.

Resting mean skin temperatures before setting out on Edale II were low in some cases, possibly because the subjects had recently risen, and much heat may have been lost from the body surface while dressing (Pugh, 1949). (The normal range for persons at rest in a comfortable thermal environment is 33.0 to $34.5^{\circ} \mathrm{C}$. by the same method).

Over the first 12 miles $(19.3 \mathrm{~km}$.) of Edale II skin temperatures fell to steady values around $31.0^{\circ} \mathrm{C}$. in the two slower groups, and to somewhat lower values in group 1 , who wore less clothing. The average value for all subjects was $30.5^{\circ} \mathrm{C}$., which was the same as the estimated value for all subjects at three check-points during Edale I (Table III). Thus, as long as the subjects were feeling warm, mean skin temperatures were similar under widely different weather conditions. Later in the day, when the subjects complained of feeling cold, mean skin temperatures in five of the six subjects were 26.5 to $27.8^{\circ} \mathrm{C}$. During the final stages mean skin temperature rose again, which was consistent with the additional clothing worn and the more sheltered conditions.

Though mean skin temperatures were closely comparable on Edale I and II as long as the subjects were feeling warm, the temperature distribution was different (Table III). The regional values were more uniform in warm weather. In cold conditions skin temperatures were lower over the limbs and either unchanged or higher over the trunk. This was an expected finding. 
TABLE III.-Average Values of Regional Skin Temperature, Weighted Mean Skin Temperature, and Gut or Rectal Temperature in WalkMean Skin Temperature, and Guarer Experiments on Subjects Exercising for Three-hour Periods in Dry and Wet Clothing (Pugh, Exercising for Three-hour Periods in Dry and Wet Clothing (Pugh, 1967). Results for Edale II were (a) Resting Values Before Setting
Out; (b) Results Collected During the First 12 Miles (19 km.) of Walking Before the Subjects Complained of Being Cold; and (c) Averages of the Minimum Values Observed on Each Subject

\begin{tabular}{|c|c|c|c|c|c|c|c|}
\hline \multirow{4}{*}{ Region } & \multirow{4}{*}{$\begin{array}{l}\text { Autumn } \\
\text { Trial. } \\
\text { Edale I } \\
6-122 \mathrm{C} . \\
\text { Slight } \\
\text { Wind. } \\
\text { Check- } \\
\text { points } \\
2,4, \\
\text { and } 5\end{array}$} & \multirow{4}{*}{$\begin{array}{c}\text { Indoors. } \\
\text { Rest } \\
\text { Before } \\
\text { Exercise }\end{array}$} & \multicolumn{2}{|c|}{$\begin{array}{l}\text { Winter Trial. } \\
\text { Edale II }\end{array}$} & \multicolumn{3}{|c|}{$\begin{array}{c}\text { Climatic Chamber } \\
\text { (Pugh, 1967) }\end{array}$} \\
\hline & & & \multicolumn{2}{|c|}{$\begin{array}{l}-2 \text { to }+2 \cdot 5^{\circ} \mathrm{C} \text {. } \\
\text { Strong Wind. } \\
\text { Dry Clothing }\end{array}$} & \multirow{3}{*}{$\begin{array}{l}20^{\circ} \mathrm{C} . \\
\text { Rest }\end{array}$} & \multirow{2}{*}{\multicolumn{2}{|c|}{$\begin{array}{c}5^{\circ} \text { C. } 9-\text { m.p.h. } \\
(14 \cdot 5-\mathrm{k} . \mathrm{p} . \mathrm{h} .) \text { Wind. } \\
\text { Exercise } 300- \\
1,200 \mathrm{~kg} . / \mathrm{min} .\end{array}$}} \\
\hline & & & & & & & \\
\hline & & & $\begin{array}{l}\text { points } \\
1 \text { and } 2\end{array}$ & $\begin{array}{l}\text { mum } \\
\text { Values }\end{array}$ & & \begin{tabular}{|} 
Dry \\
Clothing
\end{tabular} & $\begin{array}{c}\text { Wet } \\
\text { Clothing }\end{array}$ \\
\hline $\begin{array}{c}\text { No of cbserva- } \\
\text { tions }\end{array}$ & (18) & (6) & (12) & (6) & (6) & (10) & (15) \\
\hline $\begin{array}{ll}\text { Forehead (2) } & \ldots \\
\text { Hand (1) } & \ldots \\
\text { Forearm (2) } & \ldots \\
\text { Arm* }(2) & \ldots \\
\text { Trunk (4) } & \ldots \\
\text { Thight (2) } & \ldots \\
\text { Leg (2) } & \ldots \\
\text { Weighted mean } \\
\text { Gut or rectal }\end{array}$ & $\begin{array}{c}23 \cdot 9 \\
25 \cdot 4 \\
23 \cdot 9 \\
(30 \cdot 9) \\
32 \cdot 1 \\
(30 \cdot 0) \\
30 \cdot 0 \\
30 \cdot 45\end{array}$ & $\begin{array}{c}33 \cdot 6 \\
20 \cdot 5 \\
32 \cdot 3 \\
(34 \cdot 3) \\
35 \cdot 1 \\
30 \cdot 4 \\
30 \cdot 5 \\
32 \cdot 33\end{array}$ & $\begin{array}{l}28.9 \\
23.8 \\
29 \cdot 9 \\
(31.9) \\
33 \cdot 3 \\
29 \cdot 0 \\
28.0 \\
30 \cdot 47\end{array}$ & $\begin{array}{c}24 \cdot 8 \\
20 \cdot 2 \\
18 \cdot 6 \\
(20 \cdot 6) \\
32 \cdot 9 \\
28 \cdot 6 \\
24 \cdot 9 \\
27 \cdot 59\end{array}$ & $\begin{array}{l}34 \cdot 4 \\
35 \cdot 0 \\
34 \cdot 7 \\
34 \cdot 4 \\
35 \cdot 2 \\
32 \cdot 9 \\
32 \cdot 2 \\
34 \cdot 15\end{array}$ & $\begin{array}{l}29 \cdot 8 \\
31 \cdot 0 \\
30 \cdot 9 \\
32 \cdot 9 \\
33 \cdot 0 \\
28 \cdot 0 \\
28 \cdot 0 \\
30 \cdot 77\end{array}$ & $\begin{array}{l}20 \cdot 5 \\
11 \cdot 7 \\
23 \cdot 0 \\
26 \cdot 5 \\
25 \cdot 4 \\
14 \cdot 0 \\
15 \cdot 0 \\
20 \cdot 54\end{array}$ \\
\hline temp. ${ }^{\circ} \mathrm{C} . \quad .$. & $\begin{array}{l}38 \cdot 20 \\
35 \cdot 62\end{array}$ & $\begin{array}{l}36 \cdot 76 \\
35 \cdot 28\end{array}$ & $\begin{array}{l}37 \cdot 87 \\
35 \cdot 40\end{array}$ & $\begin{array}{l}37 \cdot 59 \\
34 \cdot 26\end{array}$ & $\begin{array}{l}37 \cdot 19 \\
36 \cdot 18\end{array}$ & $\begin{array}{l}37 \cdot 88 \\
35 \cdot 51\end{array}$ & $\begin{array}{l}37 \cdot 14 \\
31 \cdot 61\end{array}$ \\
\hline
\end{tabular}

* Arm values in parenthesis are interpolated as $2^{\circ} \mathrm{C}$. higher than forearm temperature.

Thigh values in parenthesis taken as equal to leg temperature. region.

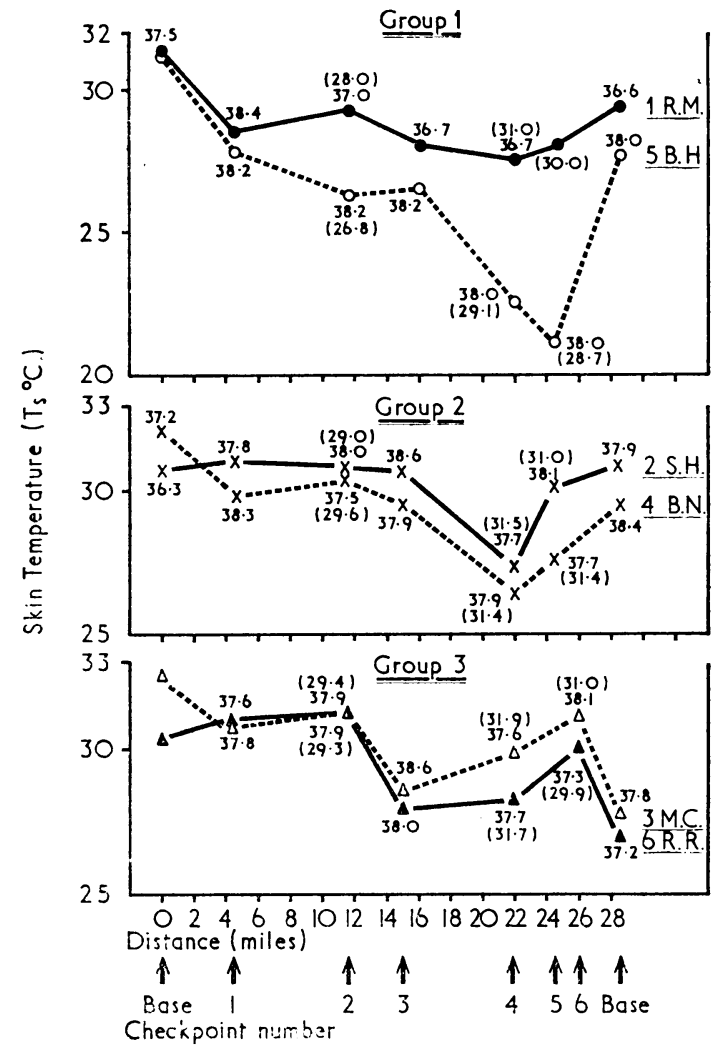

Fig. 2.-Mean skin temperatures at six check-points on the winter trial (Edale II). The corresponding gut temperatures are shown near each plotted value. Figures in parentheses are estimates of mean skin temperature at three check-points on the autumn trial (Edale I).

\section{Gut Temperature}

The gut temperature results are shown in Fig. 3. The readings for the faste: pair of walkers (group 1) are at the top of the diagram and hose of the slowest pair (group 3) are at the bottom. The resting results were collected between 07.45 and 08.00 hours about one hour after the pill had been swallowed (Fig. 3). On Edale I, where there was no question of cold stress, gut temperatures fluctuated around $38.7^{\circ} \mathrm{C}$. for group 1 and $37.9^{\circ} \mathrm{C}$. for group 3 . In most subjects the range of variation during the day was less than $\pm 0.5^{\circ} \mathrm{C}$. On Edale II the results were more variable. The fall in gut temperature to $36.7^{\circ} \mathrm{C}$. in subject R.M. of group 1 on Edale II was confirmed by a post-exercise mouth-temperature reading of $36.6^{\circ} \mathrm{C}$. compared with $37 \cdot 1^{\circ}$ C. before setting out. The association between speed of walking and gut temperature was confirmed on plotting the mean gut temperatures of each group against total time spent walking (Fig. 4). It is seen that gut temperature varied inversely with time and hence directly with mean speed. The results suggest that the somewhat lower gut temperatures on Edale II were due to slower walking rather than cold stress. Only group 1, who wore very light clothing, showed depression of gut temperature indicative of cold stress.

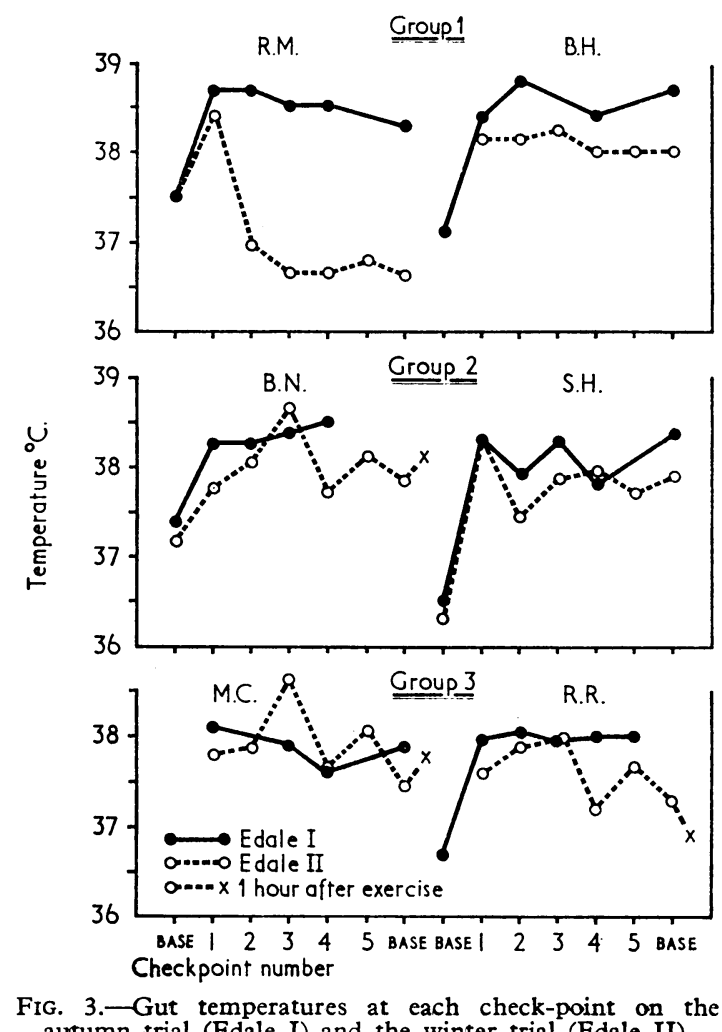

\section{Fat and Thin Subjects}

The results on R.M. and B.H. (group 1) call for special comment. These subjects walked considerably faster than the others and wore less clothing. B. H. was the only moderately fat member of the party, having a mean skinfold thickness of $7.2 \mathrm{~mm}$. He tolerated a mean skin temperature as low as $21.3^{\circ} \mathrm{C}$., his gut temperature being $38.0^{\circ} \mathrm{C}$. His companion, who was thin like the other walkers, had a mean skin temperature of $27.5^{\circ} \mathrm{C}$., which was unexpectedly high in view of his light clothing; his gut temperature on the other hand was $36.7^{\circ} \mathrm{C}$.

\section{Mean Body Temperature}

Average values of mean body temperature for Edale II and for the chamber experiments on subjects working at varying rates in dry and wet clothing (Pugh, 1967) are contained in Table III. The resting value of $36.18^{\circ} \mathrm{C}$. from the chamber experiments, which was calculated from observations at room temperature before the subjects entered the chamber, is at the upper limit of the normal comfort range-namely, 35.3 to $36.3^{\circ} \mathrm{C}$. On the other hand, resting values for Edale II, which were based on measurements made in the early morning, were lower than normal, though the subjects did not complain of being cold. During exercise the average values for Edale I, the chamber experiments, and the first 15 miles $(24 \mathrm{~km}$.) of Edale II 
were all within the range of comfort for persons at rest. The average minimum value for all subjects was $34.3^{\circ} \mathrm{C}$., which may be compared with the value of $31.61^{\circ} \mathrm{C}$. in the chamber experiments on subjects wearing wet clothing. If $35.5^{\circ} \mathrm{C}$. is taken as a baseline, these values represent heat debts of 33 and $176 \mathrm{kcal} . / \mathrm{sq}$. $\mathrm{m}$. respectively, and may be compared with the accepted tolerance limit of $80 \mathrm{kcal} . / \mathrm{sq}$. m. for U.S. and Canadian Armed Forces in the second world war (Sipple, 1945 ; Belding, 1949).

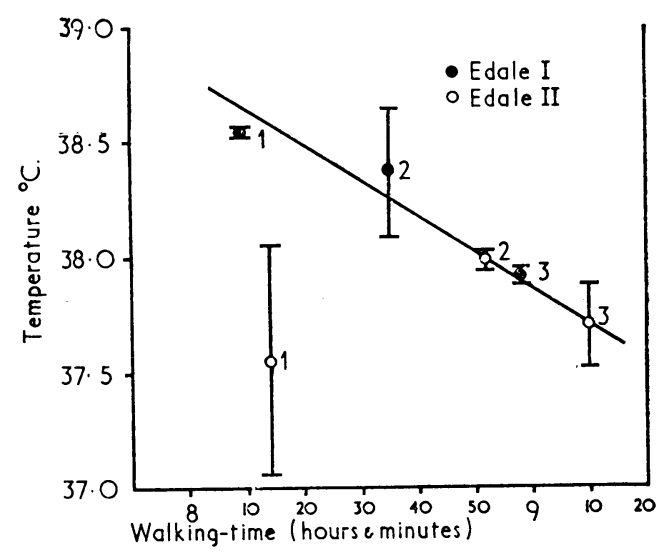

Fig. 4--Relation between mean gut temperature and time taken to walk 28 miles ( $45 \mathrm{~km}$.) (including rests) on the autumn trial (Edale I) and the winter trial (Edale II). The plotted values of gut temtrial (Edale II). The for each pair of walkers, and perature are means for each pair of whe numbers the vertical lines indicate the ranges. The numbers beside the plotted values refer to the groups. The
line relating temperature to walking-time was fitted

line relating temperature to walk
by eye.

Both walkers in group 1 had similar mean body temperatures in spite of the difference in skin and gut temperatures referred to above. Their mean body temperatures were lower than those of other subjects throughout Edale II, the ranges being from 34.7 to $32.6^{\circ} \mathrm{C}$. in R. M. (thin) and from 34.4 to $32.1^{\circ} \mathrm{C}$. in B. H. (fat). Neither subject, however, was seen shivering, nor did they confess to being more than moderately cold. This finding was consistent with their high work-rates (Pugh, 1967). Some subjects complaining of cold showed very little change in mean body temperature, and discomfort may have been due to regional skin temperature changes. Minimum mean body temperatures in Subjects S. H. and R. R., who were seen shivering, and Subject B. N., who showed mental changes, were $34.0,33.5$, and $33.6^{\circ} \mathrm{C}$., the corresponding heat debts being 43,72 , and $73 \mathrm{kcal} . / \mathrm{sq}$. m., respectively. Others with similar temperatures and heat debts complained of no more than moderate discomfort.

\section{Metabolism}

The respiratory results on Subject J. C. are contained in Table IV. Distances and gradients car be obtained by reference to Fig. 1. $\mathrm{O}_{2}$ intakes were $2 \cdot 45-2 \cdot 301 . / \mathrm{min}$. over stages conto Fining uphill sections and $2 \cdot 22-1 \cdot 341 . / \mathrm{min}$. over predominantly level and downhill sections. Fatigue may also have contributed to declining $\mathrm{O}_{2}$ intakes in the later stages. The falling respiratory exchange ratio $(R)$ was consistent with the fact

TABle IV.-Respiratory Results on Subject 7. C., Aged 18; Weight 70.1

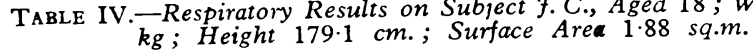

\begin{tabular}{|c|c|c|c|c|}
\hline Route & $\begin{array}{c}\text { Time } \\
\text { (min.) }\end{array}$ & $\begin{array}{c}\text { (1. BTPS } \\
\text { (1./min.) }\end{array}$ & $\begin{array}{c}. \mathrm{O}_{2} \\
(1 . / \mathrm{min} .)\end{array}$ & $\mathrm{R}$ \\
\hline $\begin{array}{l}\text { Crowden to Doctor's Gate } \\
\text { Edale to Tumulus } \\
\text { Tumaulus to spot height } \ldots \\
\text { Dove Holes to base }\end{array}$ & $\begin{array}{r}120 \\
70 \\
73 \\
60\end{array}$ & $\begin{array}{l}68.9 \\
50.7 \\
46.6 \\
39.6\end{array}$ & $\begin{array}{l}2 \cdot 48 \\
2 \cdot 20 \\
2 \cdot 22 \\
1 \cdot 84\end{array}$ & $\begin{array}{l}0.93 \\
0.86 \\
0.79 \\
0.78\end{array}$ \\
\hline
\end{tabular}
- BTPS is ventilation in litres/min. at $37^{\circ} \mathrm{C}$. observed pressure and saturated that the subject took no food. If one takes a mean $\mathrm{O}_{2}$ intake of $21 . / \mathrm{min}$. and a time of 9.5 hours, the energy cost of walking the 28 miles $(45 \mathrm{~km}$.) works out at $5,700 \mathrm{kcal}$.

\section{Food Intake and Urine}

The dietary analysis of food consumed on Edale I is contained in Table V. Energy intake was about 2,200-2,500 kcal.. with $185-431 \mathrm{~g}$. of carbohydrate. In spite of the comparatively high carbohydrate intake ketone bodies began to appear in the urine after three to five hours of walking. On Edale I, however, the amounts were smaller than on Edale II (Table V). Urine volumes, which were measured on Edale II, ranged from. 636 to $1,431 \mathrm{ml}$. Average weight loss was $0.9 \mathrm{~kg}$. on Edale I and $0.7 \mathrm{~kg}$. on Edale II.

TABLE V.-Dietary Analysis and Urinary Findings. The Results in Part A Refer to Food Consumed During Edale I. Part $B$ Shows Findings on Urine Samples at the End of Edale I and II and Total Volume of Urine Passed During Edale II

\begin{tabular}{|c|c|c|c|c|c|c|c|}
\hline \multicolumn{8}{|c|}{ A. Dietary Analysis } \\
\hline & & & Group & $\begin{array}{l}\text { Energy } \\
\text { Value } \\
\text { (kcal.) }\end{array}$ & $\begin{array}{l}\text { Pr. } \\
\text { (g.) }\end{array}$ & $\begin{array}{l}\mathrm{F} . \\
(\mathrm{g} .)\end{array}$ & $\begin{array}{l}\text { Ch. } \\
\text { (g.) }\end{array}$ \\
\hline \multicolumn{2}{|c|}{$\begin{array}{l}\text { R.M. and B.H. } \\
\text { B.N. and S.H. } \\
\text { M.C. and R.R. }\end{array}$} & & $\begin{array}{l}1 \\
2 \\
3\end{array}$ & $\begin{array}{l}2,412 \\
2,223 \\
2,541\end{array}$ & $\begin{array}{l}97 \cdot 9 \\
52 \cdot 6 \\
54 \cdot 4\end{array}$ & $\begin{array}{r}142 \cdot 3 \\
68 \cdot 5 \\
70 \cdot 3\end{array}$ & $\begin{array}{l}184.9 \\
361.6 \\
431.3\end{array}$ \\
\hline \multicolumn{2}{|c|}{ Mean } & . & & 2,393 & $68 \cdot 3$ & $93-7$ & 325.9 \\
\hline \multicolumn{8}{|c|}{ B. Urise Results } \\
\hline & & & \multicolumn{2}{|l|}{ Trial No. } & Ketones & \multicolumn{2}{|c|}{ Total Volume } \\
\hline R.M. .. & . & & \multicolumn{2}{|l|}{ II* } & $\begin{array}{l}+++ \\
+++\end{array}$ & \multicolumn{2}{|c|}{$\overline{636}$} \\
\hline B.N. .. & . & & $\begin{array}{l}\text { I } \\
\text { II }\end{array}$ & \multicolumn{2}{|r|}{$+\underset{0}{+}+$} & \multicolumn{2}{|c|}{$\overline{986}$} \\
\hline M.C. .. & .. & & $\begin{array}{l}\text { I } \\
\text { II }\end{array}$ & \multicolumn{2}{|r|}{$\begin{array}{c}++2 \\
+\end{array}$} & \multicolumn{2}{|c|}{$9 \overline{00}$} \\
\hline S.H. .. & .. & & II & \multicolumn{2}{|r|}{++} & \multicolumn{2}{|c|}{900} \\
\hline B.H. .. & .. & & $\begin{array}{l}\text { I } \\
\text { II }\end{array}$ & \multicolumn{2}{|r|}{$+\underset{0}{+}+$} & \multicolumn{2}{|c|}{$9 \overline{19}$} \\
\hline R.R. .. & .. & i & II & & $\begin{array}{l}++ \\
0+\end{array}$ & \multicolumn{2}{|c|}{$1, \overline{431}$} \\
\hline
\end{tabular}

\section{Circulation}

The circulatory observations at the check-points were unremarkable, except that heart rates were somewhat lower on Edale II, suggesting lower work rates. Fatigue at the end of the trials was associated with increase of the standing rather than the lying heart rates and increase in standing/lying heart rate differences (Table VI). The largest changes were noted in the fastest pair of walkers and in the subject showing partisl collapse (S. H.). There were no significant E.C.G. changes.

\begin{tabular}{|c|c|c|c|c|c|c|c|}
\hline \multirow{3}{*}{ Group } & \multirow{3}{*}{ Subject } & \multicolumn{5}{|c|}{ Heart Rate (Beats/min.) } & \multirow[b]{2}{*}{...... } \\
\hline & & \multicolumn{3}{|c|}{ Before } & \multicolumn{2}{|r|}{ After } & \\
\hline & & Lying & Standing & Difference & Lying & Standing & Differeace \\
\hline $\begin{array}{l}1 \\
2 \\
3\end{array}$ & $\begin{array}{l}\text { R.M. } \\
\text { B.H. } \\
\text { B.N. } \\
\text { S.H.* } \\
\text { M.C. } \\
\text { R.R. }\end{array}$ & $\begin{array}{l}74 \\
63 \\
68 \\
80 \\
80 \\
58 \\
\end{array}$ & $\begin{array}{r}78 \\
74 \\
81 \\
100 \\
92 \\
62 \\
\end{array}$ & $\begin{array}{r}+4 \\
+11 \\
+13 \\
+20 \\
+12 \\
+4 \\
\end{array}$ & $\begin{array}{r}102 \\
103 \\
105 \\
109 \\
100 \\
90 \\
\end{array}$ & $\begin{array}{r}128 \\
128 \\
108 \\
140 \\
114 \\
95 \\
\end{array}$ & $\begin{array}{r}+26 \\
+25 \\
+3 \\
+31 \\
+14 \\
+5 \\
\end{array}$ \\
\hline & Mean & 71 & 81 & $+i 1$ & 102 & 119 & +17 \\
\hline
\end{tabular}

\section{Blood Volume and Blood Constituents}

The blood volume measurements showed a small but significant increase in post-exercise blood volume, and confirmation was afforded by the lower packed cell volume (Table VII). 
These results have been published in detail elsewhere (Pugh, 1969). There were no significant changes in blood $\mathrm{pH}$ electrolytes, or other constituents except a small rise in potassium, which is a normal finding in prolonged exercise (for references see Salkin, 1964).

TABLB VII.-Blood Volume, Blood Constituents, and Body Weights on Exercise Edale I and Edale II. Mean values for Six Subjects are Shown

\begin{tabular}{|c|c|c|c|c|}
\hline & \multicolumn{2}{|c|}{ Edale I } & \multicolumn{2}{|c|}{ Edale II } \\
\hline & Before & After & Before & After \\
\hline 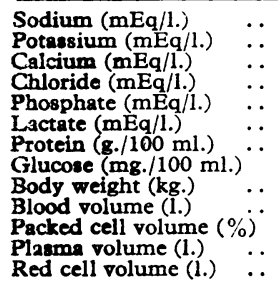 & $\begin{array}{c}142 \\
3.73 \\
8.76 \\
96 \cdot 6 \\
2.0 \\
1.78 \\
6.73 \\
78.3 \\
66.0 \\
5.18 \\
44.9 \\
2.95 \\
2.23\end{array}$ & $\begin{array}{c}142 \\
4.08 \\
9.47 \\
104.0 \\
2.21 \\
1.69 \\
6.74 \\
82.5 \\
65.1 \\
5.30 \\
43.2 \\
3.11 \\
2.19\end{array}$ & $\begin{array}{r}139 \\
3.93 \\
10.05 \\
101 \cdot 6 \\
1.78 \\
7 \cdot 3 \cdot 3 \\
59 \cdot 2 \\
66 \cdot 8 \\
5.32 \\
47 \cdot 2 \\
2 \cdot 91 \\
2 \cdot 41\end{array}$ & $\begin{array}{c}137 \\
4.12 \\
10 \cdot 65 \\
106 \cdot 3 \\
1 \cdot 79 \\
1.78 \\
7.35 \\
62 \cdot 5 \\
66.1 \\
5.62 \\
44.7 \\
3 \cdot 22 \\
2 \cdot 41\end{array}$ \\
\hline
\end{tabular}

\section{Discussion}

It is well established that in controlled conditions of temperature, air movement, and radiation the mean skin temperature during exercise depends on the cooling power of the environment, and is independent of work-rate. Most investigations in this field have been done on nude subjects (Nielsen, 1938; Robinson, 1949, 1963; Wyndham, 1965), but Belding et al. (1947) and Pugh (1967) found mean skin temperatures were independent of work-rate also in clothed subjects. Rectal temperature, on the other hand, is a straight-line function of work-rate; and is independent of the environment except in extreme conditions of heat or cold.

In outdoor activities, unlike the controlled conditions of a climatic chamber, man regulates his own skin temperature by adjusting his clothing; and evidence is presented above that the range preferred by hill-walkers is 29 to $31^{\circ} \mathrm{C}$., or 3 to $4^{\circ} \mathrm{C}$. below the comfort range for persons at rest. Rectal or gut: temperature, on the other hand, is a linear function of speed. and therefore work-rate, just as it is in chamber experiments.

The finding that the fastest pair of walkers had the highest: gut temperatures and lowest skin temperatures suggests that the comfort zone of mean skin temperature is inversely proportional to deep body temperature and therefore work-rate. Confirmation of this has been obtained in runners, who prefer mean skin temperatures of about $27^{\circ} \mathrm{C}$. when running at 9 to 10 m.p.h. ; further work along these lines is in progress.

When conditions are too cold for walkers to maintain their normal range of mean skin temperatures by adjusting their clothing, their mean skin temperatures will fall to new levels. in these circumstances many walkers tend to increase their pace, thereby raising their deep body temperatures to levels that make their low skin temperatures tolerable, and less fit members of a party may become exhausted through having to work too near to capacity (Pugh. 1967).

In still colder conditions, with skin temperatures in the region of 20 to $25^{\circ} \mathrm{C}$., it is likely that most hill-walkers cannot maintain deep body temperature at the normal level for their work-rate, even when walking at their fastest pace (except for a limited period of time). So long as rectal or gut temperature does not fall below $35^{\circ} \mathrm{C}$. they may keep going, at any rate for some hours (Pugh, 1967). In the chamber experiments referred to above subjects wearing wet clothing and working at $\mathrm{O}_{2}$ intakes of 1.0 to $1.51 . / \mathrm{min}$. showed falls of rectal temperature of 2 to $3^{\circ} \mathrm{C}$., when their mean skin temperatures were reduced to 20 to $21^{\circ} \mathrm{C}$. by wearing wet clothing ; another example is afforded by the results on Subject R.M. (Fig. 3). In the chamber experiments the subjects suffered extreme discomfort and were exhausted after three-hour periods of work 'on the ergometer, and it seems certain they would have become casuralties in less than five hours in similar conditions in the hills, this being the most common time of onset of symptoms in exposure accidents (Pugh, 1966a).

During exercise one would expect thin persons to have higher skin temperatures than fat persons, because they cannot adequately reduce heat loss by direct conduction from the active muscles to the skin surface. The findings on R. M. are consistent with this interpretation. The question then arises whether thin persons can become accustomed to reduced deep body temperature during exercise. Again the findings on R. M. suggest that they can, because he did not complain of discomfort any more than his fatter companion and was not observed to shiver at any time. Results on the other subjects also showed that there was considerable variation in the levels of body temperature at which shivering appeared in different individuals, as well as in their subjective responses to cold.

Mean body temperature has proved a useful empirical index of heat and cold stress and one that correlates well with physiological responses (Robinson, 1963). It was noteworthy to find the opposing changes in gut and skin temperature during exercise were such that mean body temperature remained virtually unchanged at rest and on exercise so long as the subjects were in a state of thermal comfort and that the heat debts calculated for subjects complaining of cold were within the accepted tolerance limits for Service personnel.

No data, as yet, are available on the level of body temperature at which consciousness is lost in "exposure" cases among hillwalkers. Victims of the infamous Dachau experiments became unconscious when their rectal temperatures fell to 30 to $31^{\circ} \mathrm{C}$. (Alexander, 1946). According to Cooper et al. (1964) some patients with hypothermia may be conscious at rectal temperatures as low as $27^{\circ} \mathrm{C}$. and others unconscious at $31^{\circ} \mathrm{C}$. An unconscious casualty having a mean skin temperature of $15^{\circ} \mathrm{C}$. and a rectal temperature of $30^{\circ} \mathrm{C}$. would have a mean body temperature of $25^{\circ} \mathrm{C}$. and heat debt of $340 \mathrm{kcal} . / \mathrm{sq} . \mathrm{m}$.

It is fair to assume that the metabolic results obtained on Subject J. C. were applicable to the fastest pair of walkers (group 1), since their speeds were similar, and they are in line with previous findings on mountaineers (see Pugh, 1967). The uniformity of the $\mathrm{O}_{2}$ intakes on J.C. as well as the uniformity of the gut temperatures in the leading pair of walkers implies that fast walkers tend to adjust their pace on uphill, downhill, and level sections in such a way as to maintain a fairly even metabolism. The slower walkers, judging by the gut temperature values, were more variable in their performance. According to the difference in times, the average $\mathrm{O}_{2}$ intake of the slowest pair was $20 \%$ less than that of the fastest pair, or about $1.61 . / \mathrm{min}$., compared with $2.01 . / \mathrm{min} .^{1}$

The variation in work tolerance observed in this group of apparently similar persons supports the argument that random grouping of walkers, without taking into account their work capacity, is dangerous in bad weather. If group 3 had been forced to keep up with group 1 they would certainly have become exhausted, and exhaustion is a principal cause of hypothermia accidents (Pugh, 1966a).

Lundgren (1946), working with lumbermen, was the first to use body temperature as an indirect measure of metabolism in long-continued exercise, and the above results on hill-walkers suggest that the method might be valuable for long-term investigations where measurement of $\mathrm{O}_{2}$ intake is difficult. The linear relation suggested by Fig. 4 must, however, be accepted with caution, since there might have been some depression of gut temperature due to cold (though the relatively high values of mean skin temperature are against this), and the slower times might have been due to the condition of the terrain rather than to lower energy expenditure.

${ }^{1} 1.7 \mathrm{l} / \mathrm{min}$. if $0.3 \mathrm{l} . / \mathrm{min}$ is allowed for non-work metabolism. 
No circulatory or metabolic changes were found which might account for the severity of symptoms in accidental hypothermia in persons who have walked to the point of exhaustion. Blood volume normally falls by 5 to $15 \%$ during the first 10 to 15 minutes of muscular exercise (for references see Pugh, 1969), and we had expected to find a further decrease in blood volume associated with exhaustion in hill-walkers. This, however, appears not to be the case, at any rate in persons who have free access to fluid and take occasional short rests. According to recent catheter studies (Ekelund, 1967), the rising heart rate and tendency to postural hypotension in persons working to exhaustion are due essentially to failure of vasomotor regulation and not to changes in blood volume. They found reduced cardiac stroke output, reduced peripheral resistance, and altered distribution of blood in the capacitance vessels.

The only positive observation bearing on fatigue was ketonuria. Subject S. H., who finished in a state of partial collapse on Edale I, showed the greatest degree of ketonuria, and there was less ketonuria on Edale II, when the subjects seemed less tired. Two months later urine samples were collected on 250 participants in a $50-$ mile $(80-\mathrm{km}$.) walking competition in the same area. The leading teams that completed the course at a run showed no ketonuria. Slower teams showed ketonuria roughly in proportion to their times. Some participants who were exhausted showed obvious mental changes in spite of the fact that the competition took place in warm weather. This was an important observation, since mental change is a common early finding in " exposure" accidents, and is usually attributed to hypothermia.

Those taking part in the investigation were Dr. K. E. Cooper and Dr. R. Johnson of the Medical Research Council Body Temperature Research Unit ; Dr. Mary Lobban, Miss Pamela Dean, and Mr. J. A. Crisp of the Division of Human Physiology, National Institute for Medical Research ; Dr. E. S. N. Fenton, Dr. G. Ll. Glynne, Dr. P. J. Andrew, and Mr. A. Edgeson of Electronics Instruments Ltd. The electrolyte and sugar determinations were done at the Biochemistry Department, the Radcliffe Infirmary, Oxford. The Rover Scouts acting as subjects were: R. McBlane,
M. G. Crome, S. S. Hatton, B. T. Hunt, R. A. Rogerson, B. Nicholson, and their team leader D. Crowley. Metabolic measurements were made on Mr. J. Cooper. The help and collaboration of all concerned is gratefully acknowledged. The research was supported by a grant from the Royal College of Surgeons' Accident Prevention Commission.

\section{REFERENCES}

Alexander, L. (1946). Publication Board Report No. 250. Washington, D.C., Department of Commerce.

Belding, H. S. (1949). In Physiology of Heat Regulation and the Science of Clothing, edited by L. H. Newburgh, p. 351. Philadelphia, Saunders.

Belding, H. S., Russell, H. D., Darling, R. C., and Folk, G. E. (1947), American fournal of Physiology, 149, 223

Burton, A. C. (1935). Fournal of Nutrition, 9, 261.

Burton, A., and Edholm, O. G. E. (1955). Man in a Cold Environment. London, Arnold.

Cooper, K. E., Hunter, A. R., and Keatinge, W. R. (1964). International Anesthesiology Clinics, 2, 999.

Edwards, D. A. W., Hammond, W. H., Healey, M. J. R., Tanner, J. M., and Whitehouse, R. H. (1955). British fournal of Nutrition, 9, 133. Ekslund, L-G. (1967). Acta Physiologica Scandinarica, 70, Suppl. No.

Fox, R. H., Goldsmith, R. H., and Wolff, H. S. (1962). fournal of Physiology, 160, 22P

Hardy, J. D. (1949). In Physiology of Heat Resulation and the Science of Clothing, edited by L. H. Newburgh, p. 78. Philadelphia, Saunders.

Lundgren, N. P. V. (1946). Acta Physiologica Scandinavica, 13, Suppl. No. 41 , p. 105 .

Nielsen, M. (1938). Skandinavisches Archiv fïr Physiologie, 79, 193.

Pugh, L. G. C. E. (1949). Report prepared for the Climatic Eficiency Sub-Committee of the Royal Naval Personnel Research Committee. (R.N.P. 49/561, C.E.S. 306.)

Pugh, L. G. C. E. (1964a). Fournal of Physiology, 170, 344.

Pugh, L. G. C. E. (1964b). Lancet, 1, 1210.

Pugh, L. G. C. E. (1964b). Lancet, 1, 1210 .

Pugh, L. G. C. E. (1966a). British Medical fournd

Pugh, L. G. C. E. (1966b). Nature, 209, 1281.

Pugh, L. G. C. E. (1967). British Medical Fournal, 2, 333

Pugh, L. G. C. E. (1969). Fournal of Fhysiology. In press.

Robinson, S. (1949). In Physiology of Heat Regulation and the Science of Clothing, edited by L. H. Newburgh, p. 193. Philadelphia, Saunders.

Robinson, S. (1963). Pediatrics, 32, 691.

Saltin, B. (1964). Acta Physiologica Scandinavica, 62, Suppl. No. 230,

Sipple, P. (1945). In Clothing Test Methods, edited by L. H. Newburgh and Milton Harris, p. 65. Washington, D.C., National Research

Wolf. H. S. (1958). Quarterly fosirnal of Experimental Physiology, 43,

Wyndham, C. H. (1965). Fournal of Applied Physiology, 20, 31.

\title{
Vincristine and Prednisone for the Induction of Remissions in Acute Childhood Leukaemia
}

\author{
R. M. HARDISTY,* M.D., M.R.C.P., F.C.PATH. ; T. J. MCELWAIN, $\dagger$ M.B., M.R.C.P. \\ CARYL W. DARBY, M.B., M.R.C.P.
}

ummary : A total of 65 children with acute lympho-
blastic leukaemia and seven with other types of
acute leukaemia received treatment with a combination of
vincristine and prednisone. In all 122 courses of treat-
ment were given. Of 22 patients with acute lymphoblastic
leukaemia who received this as their first treatment, all
achieved complete remission. The complete remission
rates were $82 \%$ for patients with acute lymphoblastic
leukaemia in their first relapse, $63 \%$ in the second
relapse, and much lower in subsequent relapses and in
the patients with other types of acute leukaemia.
Alopecia and gastrointestinal and neuromuscular toxicity
occurred respectively in $51 \%, 29 \%$ and $21 \%$ of instances, only the last of these side-effects of vincristine being doserelated. Most of the complete remissions were obtained with a total dose of vincristine which carried only a low risk of neurotoxicity.

\section{Introduction}

It is now well established that combinations of certain antileukaemic drugs are superior to the same drugs used singly for

\footnotetext{
* Professor of Haematology.

† Leukaemia Research Fellow.

Department of Haematology, Institute of Child Health, the Hospital for Sick Children, Great Ormond Street, London W.C.1.
} 